Article

\title{
Vanadium Mineralization in the Kola Region, Fennoscandian Shield
}

\author{
Alena A. Kompanchenko *(D), Anatoly V. Voloshin and Victor V. Balagansky \\ Geological Institute of the Federal Research Centre Kola Science Centre of the Russian Academy of Sciences, \\ 14 Fersman Street, Apatity 184209, Russia; anatolyvoloshin@yandex.ru (A.V.V.); \\ balagan@geoksc.apatity.ru (V.V.B.) \\ * Correspondence: komp-alena@yandex.ru; Tel.: +7-921-0488782
}

Received: 24 September 2018; Accepted: 18 October 2018; Published: 23 October 2018

\begin{abstract}
In the northern Fennoscandian Shield, vanadium mineralization occurs in the Paleoproterozoic Pechenga-Imandra-Varzuga (PIV) riftogenic structure. It is localized in sulfide ores hosted by sheared basic and ultrabasic metavolcanics in the Pyrrhotite Ravine and Bragino areas and was formed at the latest stages of the Lapland-Kola orogeny 1.90-1.86 Ga ago. An additional formation of vanadium minerals was derived from contact metamorphism and metasomatism produced by the Devonian Khibiny alkaline massif in the Pyrrhotite Ravine area. Vanadium forms its own rare minerals (karelianite, coulsonite, kyzylkumite, goldmanite, mukhinite, etc.), as well as occurring as an isomorphic admixture in rutile, ilmenite, crichtonite group, micas, chlorites, and other minerals. Vanadium is inferred to have originated from two sources: (1) basic and ultrabasic volcanics initially enriched in vanadium; and (2) metasomatizing fluids that circulated along shear zones. The crystallization of vanadium and vanadium-bearing minerals was accompanied by chromium and scandium mineralization. Vanadium mineralization in Paleoproterozoic formations throughout the world is briefly considered. The simultaneous development of vanadium, chromium and scandium mineralizations is a unique feature of the Kola sulfide ores. In other regions, sulfide ores contain only two of these three mineralizations produced by one ore-forming process.
\end{abstract}

Keywords: vanadium mineralization; mineralogy; Paleoproterozoic; Kola region; Arctic zone; Fennoscandian Shield

\section{Introduction}

Vanadium is a fairly widespread element. It is present in all major types of rocks of the Earth's crust, in meteorites, spectra of stars and the Sun. The vanadium content in the Earth's crust is estimated at $1.6 \times 10^{-2}$ mass $\%$ and in oceans $3.0 \times 10^{-7}$ mass \% [1]. Vanadium in the Earth's crust can create compounds or be present in them in the form of $\mathrm{V}^{3+}, \mathrm{V}^{4+}$ and $\mathrm{V}^{5+}$.

Vanadium and vanadium-bearing minerals are formed in different genetic settings. In minerals of magmatic rocks vanadium is found mainly in the trivalent form as an isomorphic admixture. Typical Fe-Ti-V ores are related to mafic-ultramafic rocks (for example, the Kolvitsa massif in the Kola region [2], the Bushveld layered intrusion in South Africa [3,4], and the Pan-Xi intrusion in China [5,6]). In these ores, vanadium is present predominantly in oxide minerals as an isomorphic admixture. In the Buena Vista Hills Fe-V deposit in Nevada (USA), submicroscopic exsolution lamellae of coulsonite $\mathrm{FeV}_{2} \mathrm{O}_{4}$ were revealed in magnetite [7]. Rare vanadium minerals were discovered in rocks initially enriched with vanadium and metamorphosed up to amphibolite facies. For example, tanzanite, a blue vanadium-bearing variety of zoisite, is an extremely rare mineral and occurs in the only deposit of tanzanite in the world in Tanzania [8]. Natalyite $\mathrm{NaVSi}_{2} \mathrm{O}_{6}$ [9], magnesiocoulsonite $\mathrm{MgV}_{2} \mathrm{O}_{4}$ [10], 
oxyvanite $\mathrm{V}^{3+}{ }_{2} \mathrm{~V}^{4+} \mathrm{O}_{5}[11]$ were found among other vanadium minerals in the Sludyanka complex in the southern Baikal area (Russia).

A wide variety of vanadium minerals has been established in metamorphosed massive sulfide ores, described so far only in supracrustal units of several Paleoproterozoic riftogenic structures of the ancient shields of the world. Vanadium mineralization in sulfide ores was reported in the Kola region in Russia [12-14], the Outokumpu and Vihanti deposits in Finland [15,16], the Sätra deposit in Sweden [17], and the Rampura Agucha deposit in India [18]. The Outokumpu and Sätra deposits are the type of localities for karelianite $\mathrm{V}_{2} \mathrm{O}_{3}$ and vuorelainenite $\mathrm{MnV}_{2} \mathrm{O}_{4}$, respectively [15,17]. All these massive sulfide ore deposits and occurrences were formed c. $1.9 \mathrm{Ga}$ ago and were metamorphosed up to amphibolite or even granulite facies. This work gives a comprehensive description of the vanadium mineralization in the Paleoproterozoic Pechenga-Imandra-Varzuga (PIV) riftogenic structure in the northern Fennoscandian Shield. It bases on the authors' data on the Pyrrhotite Ravine deposit and the Bragino occurrence of sulfide ores and literature data on a vanadium mineralization in xenoliths of Paleoproterozoic supracrustal rocks in the Devonian Khibiny alkaline massif. This work also contains a brief comparative analysis of vanadium mineralization in the Paleoproterozoic supracrustal units of the ancient shields of the world.

\section{Geological Setting}

The Polmak-Pasvik-Pechenga-Imandra-Varzuga riftogenic belt (further, Pechenga-Varzuga) is located in a transitional zone between the orogenic core and north-eastern foreland of the Paleoproterozoic Lapland-Kola collisional orogen $[19,20]$ (Figure 1). This belt is a detailed geological record of the Paleoproterozoic in the Fennoscandian shield [21-25]. It includes an almost complete Paleoproterozoic stratigraphy and all major types of Paleoproterozoic plutonic rocks in northern Fennoscandia. Its largest and well studied Pechenga and Imandra-Varzuga structures are located in the Kola region (Figure 1) and are described in detail in [22].

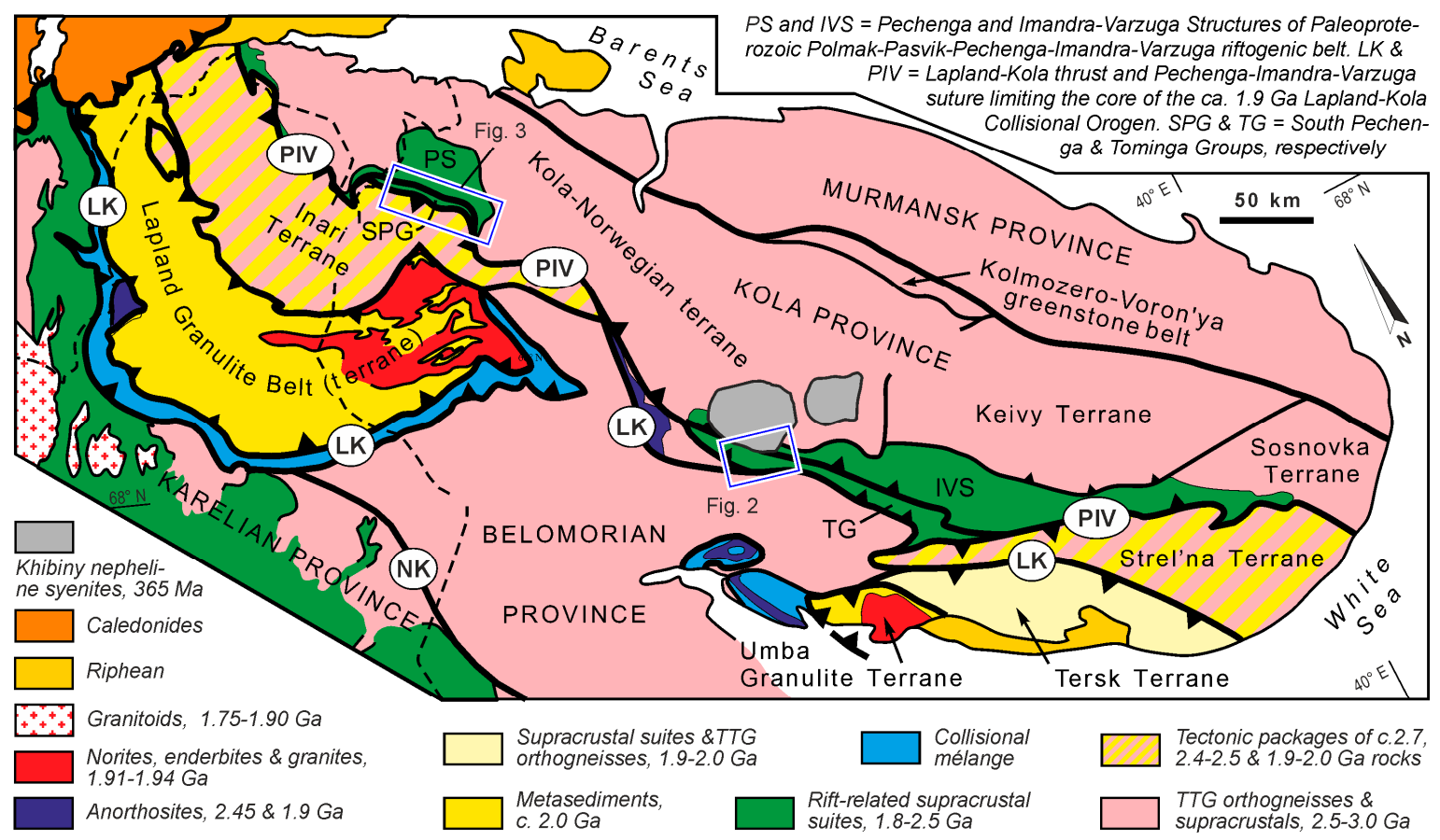

Figure 1. Tectonic map of the northern Fennoscandian Shield (modified from $[19,20]$ ).

\subsection{Imandra-Varzuga Structure}

This structure consists of wide northeastern and narrow southwestern structural zones [22,26] (Figure 1). The former extends along the entire Imandra-Varzuga structure, whereas the latter is 
exposed only in its central and western parts. The north-eastern zone is appoximately a SW-dipping monocline. In the south-western zone rocks dip steeply to the south-west and north-east and are locally intensely tectonized and folded. Rocks are thrust over Archean basement gneisses in the western portion of the structure and are tectonically overlain by these gneisses in its central portion. Both the zones were metamorphosed under conditions of greenschist to amphibolite facies [27].

The Imandra-Varzuga stratigraphy consists of three groups (from bottom to top): Strelna, Varzuga, and Tominga [22,26]. The Strelna and Varzuga groups are dominated by basic metavolcanics (hereafter "meta" is omitted) and occur only in the north-eastern zone. The Strelna Group was more likely deposited from 2.53 Ga to 2.41 Ga or even to 2.36 Ga [24]. The deposition of the Varzuga Group took place appoximately during the Lomagundi-Jatuli ${ }^{13} \mathrm{C}$ excursion that occurred 2.28-2.05 Ga ago [23].

The Tominga Group is present only in the south-western zone (Figure 2). Apart from basic volcanics, it contains intermediate and felsic volcanic rocks. All these volcanics are alternated with sediments including graphite-bearing "black" schists. Five lithic units are established which may correspond to formations [26] but an accepted stratigraphy is lacking. The depositional environment of the Tominga Group differed considerably from that of the Strelna and Varzuga groups [26]. The Tominga supracrustal section appears to be tectonostratigraphical [23]. A Sm-Nd model age of a rhyodacite is $2.02 \mathrm{Ga}$ [20], which suggests its origination from a middle Paleoproterozoic juvenile source. Sediments of the lower part of the Tominga Group are intruded by 1.94 Ga old granites and subvolcanic trachidacites of the upper part are dated at $1.91 \mathrm{Ga}$ [28]. Felsic volcanics have an imprecise $\mathrm{Rr}-\mathrm{Sr}$ isochron age of $1.87 \pm 0.07 \mathrm{Ga}$ [29].
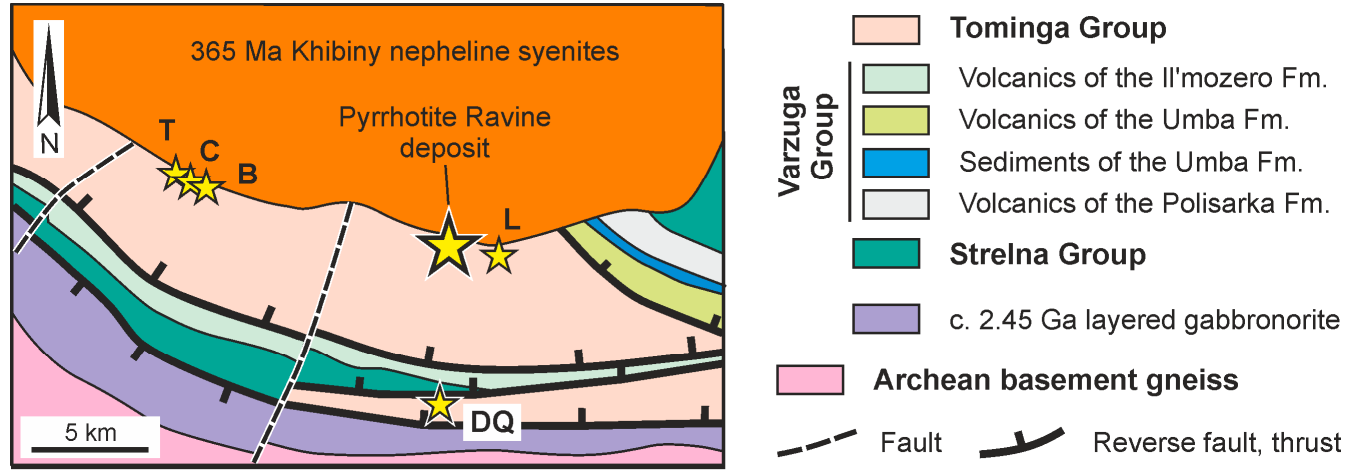

Sulfide ore occurrences: B, Basic; C, Central; DQ, Dolomite Quarry; L, Lovchorrjok; T, Takhtar

Figure 2. Geological map of the western Imandra-Varzuga structure (modified from [23]).

\subsection{Pechenga Structure}

The stratigraphy and architecture of the Pechenga structure is principally close to that of the Imandta-Varzuga structure but a counterpart of the Strelna Group which is lowermost is lacking in Pechenga. The Pechenga structure also consists of two zones, the wide Northern zone and the narrow Southern zone [23,30].

In the Northern zone rocks are folded into an open syncline (Figure 1) whose hinge line plunges at intermediate angle southwestwards in surface and gentler at depth. These were metamorphosed under lower greenschist/intermediate amphibolite facies conditions [27]. The stratigraphy of this zone is well studied on the surface and is supported by data on the Kola supedeep borehole [25,31]. It consists of rocks of the Pechenga [32] or North Pechenga Group [23] and is consistent with that of the Varzuga Group [32]. This congruence is supported by isotopic ages and data on stable isotopes of carbon (Lomagundi-Jatuli event [23,33-35]). A badly constrained Rb-Sr isochron age of $2.32 \mathrm{Ga}$ was obtained for basic volcanics of the basal part of the the North Pechenga Group [30,36]. The deposition of basic volcanics and felsic tuffs of the uppermost part of this group and the emplacement of related intrusive rocks happened c. 1.98-1.99 Ga ago [23,33]. 
In the Southern zone rocks occur steeply or vertically. Reverse faults and thrusts limit this zone and dip deeply southwards and gentler at depth $[24,30]$. The south-western margin of the Southern zone is folded due to thrusting on it of the Kaskeljavr diorite and Shuoni sodic granite massifs (Figure 3). The South Pechenga rocks were metamorphosed under upper greenschist/intermediate amphibolite facies conditions [27]. These are often cataclized, mylonitized and metasomatically changed [37].

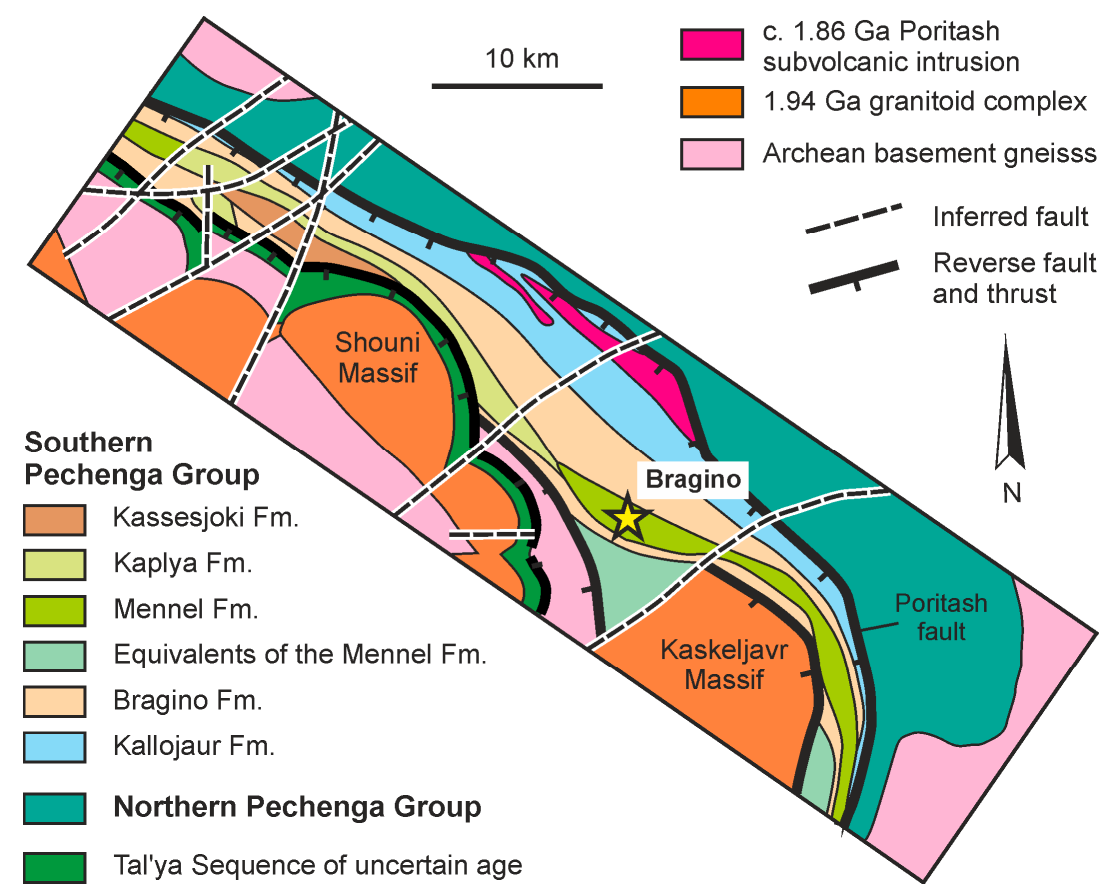

Figure 3. Geological map of the South Pechenga structural zone composed of the Southern Pechenga Group (modified from [23]).

A conventional stratigraphy of the Southern zone is lacking. According to $[23,30]$, the stratigraphical section consists (from bottom to top) of the Kallojaur, Bragino, Mennel, Kaplya, and Kassesjoki formations of the South Pechenga Group [23,32] or the Ansemjoki and Porojärvi Groups [30]. A characteristic feature of the South Pechenga Group are rhythmically layered graphite-bearing "black" schists and a large amount of intermediate and felsic volcanics. There are imprecise $\mathrm{Rb}$-Sr isochron whole-rock ages of $1.87 \pm 0.06 \mathrm{Ga}$ and $1.86 \pm 0.05 \mathrm{Ga}$ [36] and an imprecise $\mathrm{Sm}-\mathrm{Nd}$ age of $1.89 \pm 0.04 \mathrm{Ga}$ [38]. It is possible that the Kaskeljavr diorites and the Shouni sodic granites dated at 1.94-1.95 Ga [39,40] are related to the South Pechenga intemediate and felsic volcanics (see a review in [23]). If it is the case, the South Pechenga Group is a counterpart of the Tominga Group.

\section{Methods}

The study of ore minerals in reflected light was conducted in optical microscope Axioplane. Minerals were identified based on their chemical compositions, Raman spectra, X-ray diffraction, and Electron Back Scattered Diffraction (EBSD). Chemical analyses of minerals were carried out by means of a Cameca MS-46 electron probe microanalyzer (Geological Institute, Kola Science Centre of the RAS, Apatity, Russia). Element distribution, morphology and intraphase heterogeneity also was determined using a LEO-1450 scanning electron microscope (SEM) (Carl Zeiss, Oberkochen, Germany) equipped with a Bruker XFlash-5010 Nano GmbH (Bruker, Bremen, Germany) energy-dispersive spectrometer (EDS) and a SEM Hitachi S-3400N (Hitachi, Tokyo, Japan) equipped with a EDS Oxford X-Max 20 (Oxford Instruments, Abington, UK). X-ray powder diffraction patterns were obtained on an URS 55b diffractometer. Raman spectra of minerals were measured by using an Almega XR ThermoScientific spectrometer (Thermo Fisher Scientific, Waltham, MA, USA) equipped with a 
confocal microscope Olympus BX51 with a $100 \times$ objective $(532 \mathrm{~nm})$ and a Horiba Jobin Ivon LABRam HR800 (HORIBA Scientific, Kyoto, Japan) spectrometer equipped with a confocal microscope Olympus BX41 with a $50 \times$ objective $(488,514 \mathrm{~nm})$. An EBSD analysis was conducted on a SEM Hitachi S-3400N (Hitachi, Tokyo, Japan) equipped with an Oxford HKL Nordlys Nano detector (Oxford Instruments, Abington, UK). The chemical compositions of the mentioned minerals is available from the first author on request.

\section{Vanadium Mineralization in the Kola Region}

Basic volcanics of the Tominga and South Pechenga groups host massive sulfide ores. The Pyrrhotite Ravine deposit and the Basic, Central, Lovchorrjok and Takhtar occurrences of these ores are situated in the Imandra-Varzuga structure and the Bragino occurrence in the Pechenga structure (Figures 2 and 3). There are four textural types of sulfide ores: massive, banded, interspersed, and breccia-like. All ore types bear a vanadium mineralization [12,14]. The sulfide ores in both study areas were metamorphosed under epidote-amphibolite up to amphibolite facies during the Paleoproterozoic Lapland-Kola collisional orogeny. Their common feature is the high concentration of pyrrhotite in all studied ores (up to $95 \%$ ). Another common feature is that all ores contain almost no galena.

Vanadium minerals always have an isomorphic admixture of chromium. The $\mathrm{Cr}$ content is markedly higher in oxide minerals than in silicates. The $\mathrm{Cr}$ content in vanadium minerals of the Bragino ores that are hosted by the ultrabasic volcanics is much higher than in vanadium minerals of Pyrrhotite Ravine ores hosted by basic volcanics.

\subsection{Pyrrhotite Ravine Sulfide Ore Deposit}

In the Imandra-Varzuga structure the vanadium mineralization was studied in the Pyrrhotite Ravine sulfide ore deposit (Figure 2). This deposit is situated in hornfels after basalts and picritobasalts of the Tominga Group. The hornfels were formed by the contact metamorphism resulting from the Khibiny alkaline massif [41], and this metamorphism affected sulfide ores. These volcanics were originally metamorphosed under biotite-chlorite-actinolite subfacies of greenschist facies [26]. Compared to other basic volcanics of the western Imandra-Varzuga structure they are characterized by elevated concentrations of $\mathrm{V}$ and $\mathrm{Ti}$ [42]. Abnormally high $\mathrm{V}$ contents were established in the Tominga graphite-bearing schists (the so-called black schists) but the origins of this anomaly and V containers have remained unclear [43].

The main ore mineral is pyrrhotite. Sphalerite, chalcopyrite, pyrite and molybdenite are the most common sulfides. The most typical accessory minerals are titanite, rutile, ilmenite, etc. Rare and single findings of argentopentlandite, breithauptite, pentlandite, brannerite, complex oxides of U-Pb composition, etc. are described. A noble metal mineralization is represented by gold, silver and their tellurides [13].

The vanadium mineralization in the Pyrrhotite Ravine sulfide ores are represented by four vanadium minerals (karelianite, coulsonite, goldmanite $\mathrm{Ca}_{3} \mathrm{~V}_{2}\left(\mathrm{SiO}_{4}\right)_{3}$ and mukhinite $\mathrm{Ca}_{2}\left(\mathrm{Al}_{2} \mathrm{~V}\right)\left[\mathrm{Si}_{2} \mathrm{O}_{7}\right]\left[\mathrm{SiO}_{4}\right] \mathrm{O}(\mathrm{OH})$ ) and a large number of vanadium-bearing minerals (rutile, ilmenite, crichtonite group, micas, chlorites and etc.) (Table 1). Karelianite and coulsonite are usually found as relicts and highly corroded crystals surrounded by overgrowths of mukhinite, goldmanite and a mineral phase conditionally named "vanadomukhinite" (Figure 4a,b). "Vanadomukhinite" is a potentially new mineral of the epidote group which contains up to 22 mass $\%$ of $\mathrm{V}_{2} \mathrm{O}_{3}$ versus $10-12$ mass $\%$ of $\mathrm{V}_{2} \mathrm{O}_{3}$ in mukhinite [13]. 

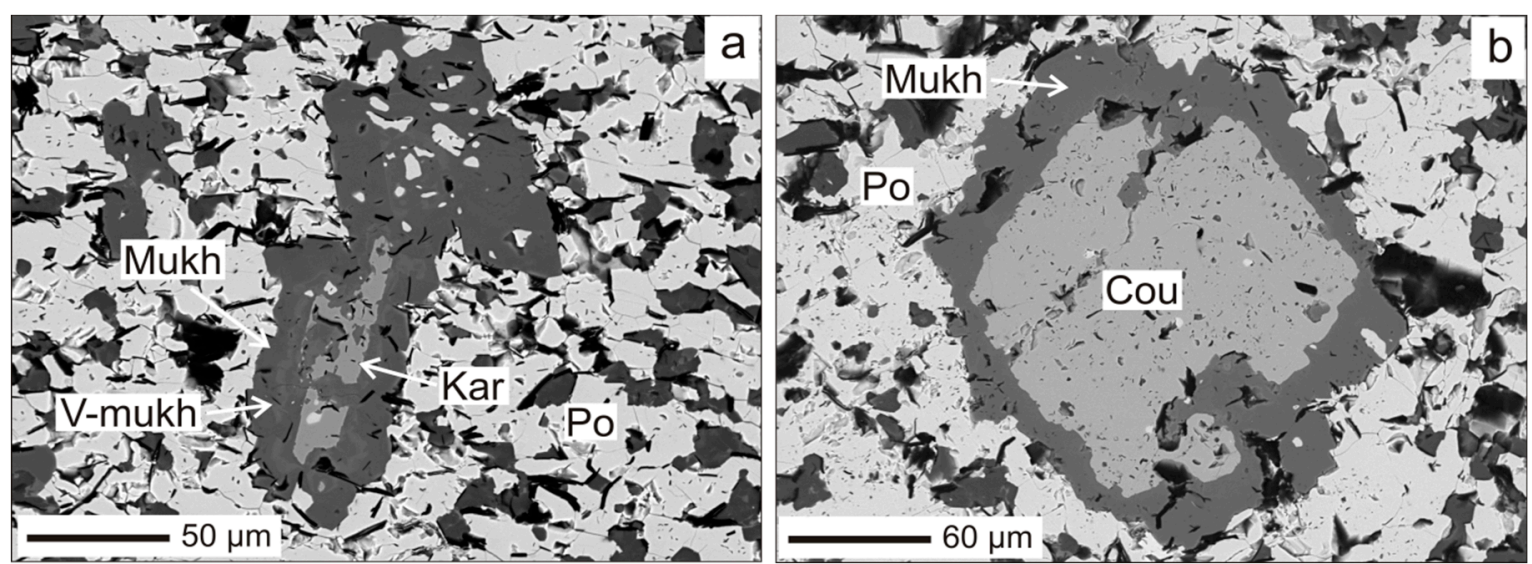

Figure 4. Vanadium mineralization in Pyrrhotite Ravine sulfide ore: karelianite (a) and coulsonite (b) with rim of vanadium silicates. Back-scattered electron (BSE) images. Cou, coulsonite; Kar, karelianite; Mukh, mukhinite; Po, pyrrhotite; V-mukh, vanadomukhinite. Mineral abbreviations hereafter on [44] apart from introduced by the authors for rare minerals.

Table 1. Major V-Cr-Ti-Sc-bearing minerals in some sulfide ore deposits in the Kola Region and throughout the world.

\begin{tabular}{|c|c|c|c|c|c|c|c|c|c|}
\hline Mineral/Area & PR & $\mathrm{Br}$ & Vih & Otk & Sät & RA & Ctl & DC & Bgj \\
\hline \multicolumn{10}{|c|}{ Oxides } \\
\hline Berdesinskiite & - & - & + & - & - & - & + & - & - \\
\hline Burydite & - & + & - & - & - & - & - & - & - \\
\hline Chromite & - & + & - & + & - & - & + & - & + \\
\hline Coulsonite & + & + & + & - & - & + & + & - & - \\
\hline Crichtonite & + & + & - & - & - & - & - & + & - \\
\hline Davidite-(Ce) & + & + & - & - & - & - & - & - & + \\
\hline Davidite-(La) & + & + & - & - & - & - & - & - & + \\
\hline Eskolaite & - & - & - & + & - & + & - & - & - \\
\hline Ilmenite & + & + & - & - & - & - & - & + & - \\
\hline Karelianite & + & - & + & + & + & + & - & - & - \\
\hline Kyzylkumite & - & + & + & - & - & - & - & - & - \\
\hline Lindsleyite & - & + & - & - & - & - & - & - & - \\
\hline Loveringite & + & - & - & - & - & - & - & - & + \\
\hline Nolanite & - & + & + & + & - & - & - & - & - \\
\hline Rutile & + & + & + & - & - & + & - & + & - \\
\hline Senaite & - & + & - & - & - & - & - & - & - \\
\hline Shcherbinaite & - & - & + & - & - & - & - & - & - \\
\hline Schreyerite & - & + & + & - & - & + & - & - & - \\
\hline Tivanite & - & + & + & - & - & - & - & - & - \\
\hline \multicolumn{10}{|c|}{ Silicates } \\
\hline Aegirine & - & - & - & - & - & - & - & + & - \\
\hline "Braginoite" & - & + & - & - & - & - & - & - & - \\
\hline Chamosite & + & + & - & - & - & - & - & + & + \\
\hline Clinochlore & + & + & - & + & - & - & - & - & - \\
\hline Diopside & + & - & - & + & - & - & - & - & - \\
\hline Fuchsite & - & - & - & + & - & - & - & - & - \\
\hline Goldmanite & + & - & - & - & - & - & + & - & - \\
\hline Jervisite & - & + & - & - & - & - & - & + & - \\
\hline Mukhinite & + & - & - & - & - & - & - & - & - \\
\hline Muscovite & + & + & - & - & - & - & - & - & - \\
\hline Natalyite & - & - & - & - & - & - & - & + & - \\
\hline Phlogopite & + & + & - & - & - & - & - & - & - \\
\hline
\end{tabular}


Table 1. Cont.

\begin{tabular}{cccccccccc}
\hline Mineral/Area & PR & Br & Vih & Otk & Sät & RA & Ctl & DC & Bgj \\
\hline Roscoelite & - & + & - & - & - & - & - & - & - \\
Thortveitite & - & + & - & - & - & - & - & + & + \\
Uvarovite & - & - & - & + & - & - & - & - & - \\
"Vanadomukhinite" & + & - & - & - & - & - & - & - & - \\
"Vanadoallanite-(Ce)" & - & + & - & - & - & - & - & - & - \\
"Vanadoallanite-(Nd)" & - & + & - & - & - & - & - & - & - \\
\hline
\end{tabular}

Note: Br, Bragino (this study); Bgj, Biggejavri [45]; Ctl, Catalonia [46]; DC, Deadhorse Creek [47]; Otk, Outokumpu [15]; PR, Pyrrhotite Ravine ([13,14] this study); RA, Rampura Agucha [18]; Sät, Sätra [17]; Vih, Vihanty [16]; "+", mineral established; "- ", no data; quotes indicate minerals that have no exact analogs among known minerals and their names are conditional.

In the Pyrrhotite Ravine deposit, the vanadium mineralization was formed in two stages [13]. At the first stage, primary oxides (karelianite, coulsonite) were crystallized as a result of vanadium redistribution during a regional metamorphism of V-rich protoliths of basic volcanics. At the second stage, calcium-vanadium silicates were developed in skarns originated from a contact metamorphism of sulfide ores and calcium introduction into them due to an influence of the giant Devonian Khibiny alkaline intrusion.

\subsection{Bragino Sulfide Ore Occurrence}

The Bragino sulfide ore occurrence is located in picrobasalts of the Mennel Formation occurring among rocks of the Bragino Formation (Figure 3). Apart from basic volcanics, the Bragino Formation contains graphite-bearing tuffogenic sandstones and alevrolites with subordinate sulfide-graphite-bearing schists. The rocks experienced intensive metamorphic and deformational reworking and their greater part was changed in blastomylonites, mylonites and cataclasites in shear zones developed during the Paleoproterozoic Lapland-Kola collision. The Mennel basic volcanics are depleted by $\mathrm{K}, \mathrm{Sr}, \mathrm{Rb}, \mathrm{Ta}, \mathrm{Zr}, \mathrm{Hf}$, Ti, light rare-earth elements, and heavy rare-earth elements, are enriched by $\mathrm{Ba}, \mathrm{Th}, \mathrm{Nb}$, and belong to low-alkali and Fe-Mg-enriched rocks of the normal-type mid-ocean ridge basalts [48].

In Bragino, similar to the Pyrrhotite Ravine, the main sulfide is pyrrhotite which can build up to $95 \%$ of ores. A massive coarse-grained pyrite ore in which pyrite forms euhedral crystals was found in pyrrhotite ores. Sphalerite, chalcopyrite and marcasite are established among the most common sulfides. Molybdenite, arsenopyrite, cobaltite, gold, and tellurides of $\mathrm{Au}, \mathrm{Ag}, \mathrm{Bi}$, and $\mathrm{Pd}$ are also revealed. Non metallic minerals include quartz, albite, siderite, calcite, apatite, monazite, xenotime, micas, and chlorites [12]. The $\mathrm{V}_{2} \mathrm{O}_{5}$ content is less than 0.025 mass \% in the sulfide ores.

The vanadium mineralization is represented by oxides and silicates (Table 1). All vanadium oxides may be divided into $\mathrm{Fe}-\mathrm{V}$ and Ti-V groups. Among the $\mathrm{Fe}-\mathrm{V}$ oxides coulsonite and nolanite $\left(\mathrm{V}^{3+}, \mathrm{Fe}^{3+}, \mathrm{Fe}^{2+}\right)_{10} \mathrm{O}_{14}(\mathrm{OH})_{2}$ are revealed. Coulsonite was found in all types of the sulfide ores and is the most common vanadium mineral. It is characterized by a changeable composition due to the isomorphic substitution between $\mathrm{V}^{3+}, \mathrm{Cr}^{3+}$ and $\mathrm{Fe}^{3+}$. Chromite $\left(\mathrm{FeCr}_{2} \mathrm{O}_{4}\right)$ relicts were established in some crystals of coulsonite [12]. Coulsonite crystalls have variable size and morphology and the largest octahedral crystals are 300-500 $\mu \mathrm{m}$ across (Figure 5a). Coulsonite occurs in close intergrowths with V-bearing ilmenite (Figure $5 b$ ) and V-W-bearing rutile (Figure $5 \mathrm{c}$ ). Nolanite was found exclusively in pyrite ores in which it is located in microcracks in coulsonite (Figure 5d).

The Ti-V oxides are represented by extremely rare minerals kyzylkumite $\mathrm{Ti}_{2} \mathrm{VO}_{5}(\mathrm{OH})$, tivanite $\mathrm{TiVO}_{3}(\mathrm{OH})$ and byrudite $(\mathrm{Be}, \square)(\mathrm{V}, \mathrm{Ti})_{3} \mathrm{O}_{9}$. Kyzylkumite, like nolanite, was discovered exclusively in massive pyrite ores in which it forms individual crystals in pyrite, intergrows with $\mathrm{V}$-W-bearing rutile (Figure $5 \mathrm{e}$ ) and is associated with $\mathrm{Sc}-\mathrm{V}$-bearing crichtonite group minerals (up to 23 mass \% of $\mathrm{V}_{2} \mathrm{O}_{3}$ and 3 mass $\%$ of $\mathrm{Sc}_{2} \mathrm{O}_{3}$ ). Tivanite and byrudite were established in relics of quartz-albite 
veins (see below). These minerals usually occur together and form thin exolution lamellae in V-W-rutile. Byrudite sometimes forms individual crystals in association with other vanadium and vanadium-bearing minerals (Figure 5f). Tivanite and anorther mineral, tentatively classified as byrudite, were determined from the presence of $\mathrm{TiO}_{2}$ and $\mathrm{V}_{2} \mathrm{O}_{3}$ as the main components in their chemical compositions and from crystal lattices obtained by an X-ray spectral analysis and an EBSD method, respectively. However, the byrudite chemical composition is significantly different from that of byrudite from the Byrud mine in Norway [49] and needs further study.

Intergrowths of vanadium-bearing allanite subgroup minerals (up to 12 mass $\%$ of $\mathrm{V}_{2} \mathrm{O}_{3}$ ) were found in association with thortvetite $\mathrm{Sc}_{2} \mathrm{Si}_{2} \mathrm{O}_{7}, \mathrm{~V}$-bearing muscovite and monazite. According to their chemical composition, these minerals may be neodymium and cerium analogs of vanadoallanite-(La) $\mathrm{CaLa}\left(\mathrm{VAlFe}^{2+}\right)\left[\mathrm{Si}_{2} \mathrm{O}_{7}\right]\left[\mathrm{SiO}_{4}\right] \mathrm{O}(\mathrm{OH})$, and are conditionally named "vanadoallanite-(Nd)" and "vanadoallanite-(Ce)". In addition, a V-Al silicate was discovered which forms both single grains and rims around roscoelite $\mathrm{KV}^{3+}{ }_{2}\left(\mathrm{Si}_{3} \mathrm{Al}\right) \mathrm{O}_{10}(\mathrm{OH})_{2}$. Its chemical composition has no analog among vanadium-bearing and vanadium minerals, and its Raman spectrum is close to that of the chlorite group. We think that it may be a new vanadium-bearing chlorite phase, conditionally named "braginoite". This and the allanite subgroup minerals also need further study.
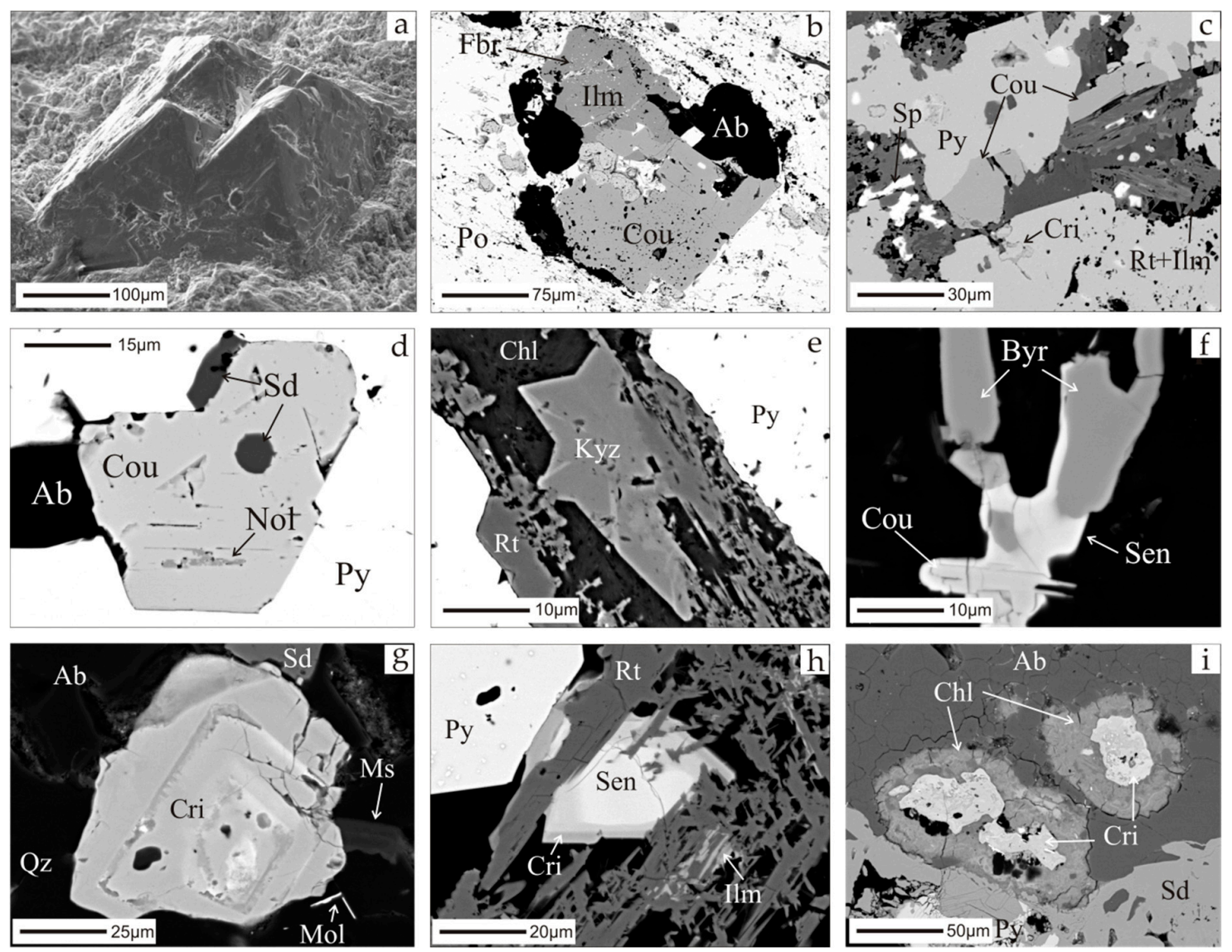

Figure 5. Vanadium and vanadium-bearing minerals in the Bragino massive sulfide ores: (a-d) Fe-V oxides; (e,f) Ti-V oxides; (g,h) Sc-V-bearing crichtonite group minerals (a-i), secondary electron and back-scattered electron images, respectively; $\mathrm{Ab}$, albite; Byr, byrudite; Chl, chlorite; Cou, coulsonite; Cri, cricthonite group minerals; Fbr, ferberite; Ilm, ilmenite; Kyz, kyzylkumite; Ms, muscovite Mol, molybdenite; Po, pyrrhotite; Py, pyrite; Qz, quartz; Rt, rutile; Sd, siderite; Sen, senaite; Sp, sphalerite).

As an isomorphic admixture, vanadium is detected in ilmenite and rutile (up to 3 mass \% and 11 mass \% of $\mathrm{V}_{2} \mathrm{O}_{3}$, respectively), the mica group (roscoelite, muscovite with 3 mass $\%$ of $\mathrm{V}_{2} \mathrm{O}_{3}$, 
and phlogopite with 5 mass $\%$ of $\mathrm{V}_{2} \mathrm{O}_{3}$ ), the chlorite group (up to 12 mass $\%$ of $\mathrm{V}_{2} \mathrm{O}_{3}$ in chamosite and up to 3 mass \% of $\mathrm{V}_{2} \mathrm{O}_{3}$ in clinochlore), and titanite (up to 5 mass \% of $\mathrm{VO}_{2}$ ).

The Bragino pyrite and pyrrhotite ores contain numerous elongated relics of quartz-albite veins dimensions of which vary from $1 \times 2$ to $10 \times 50 \mathrm{~mm}$ (Figure $6 \mathrm{a}-\mathrm{c}$ ). The relics have zigzag-like contacts and their tiny fragments are observed in the sulfide ores along these contacts. This suggests their dissolution and replacement during the ore formation. The relics are often situated close to each other, their orientation is irregular but some of them form chains which appear to trace former veins.
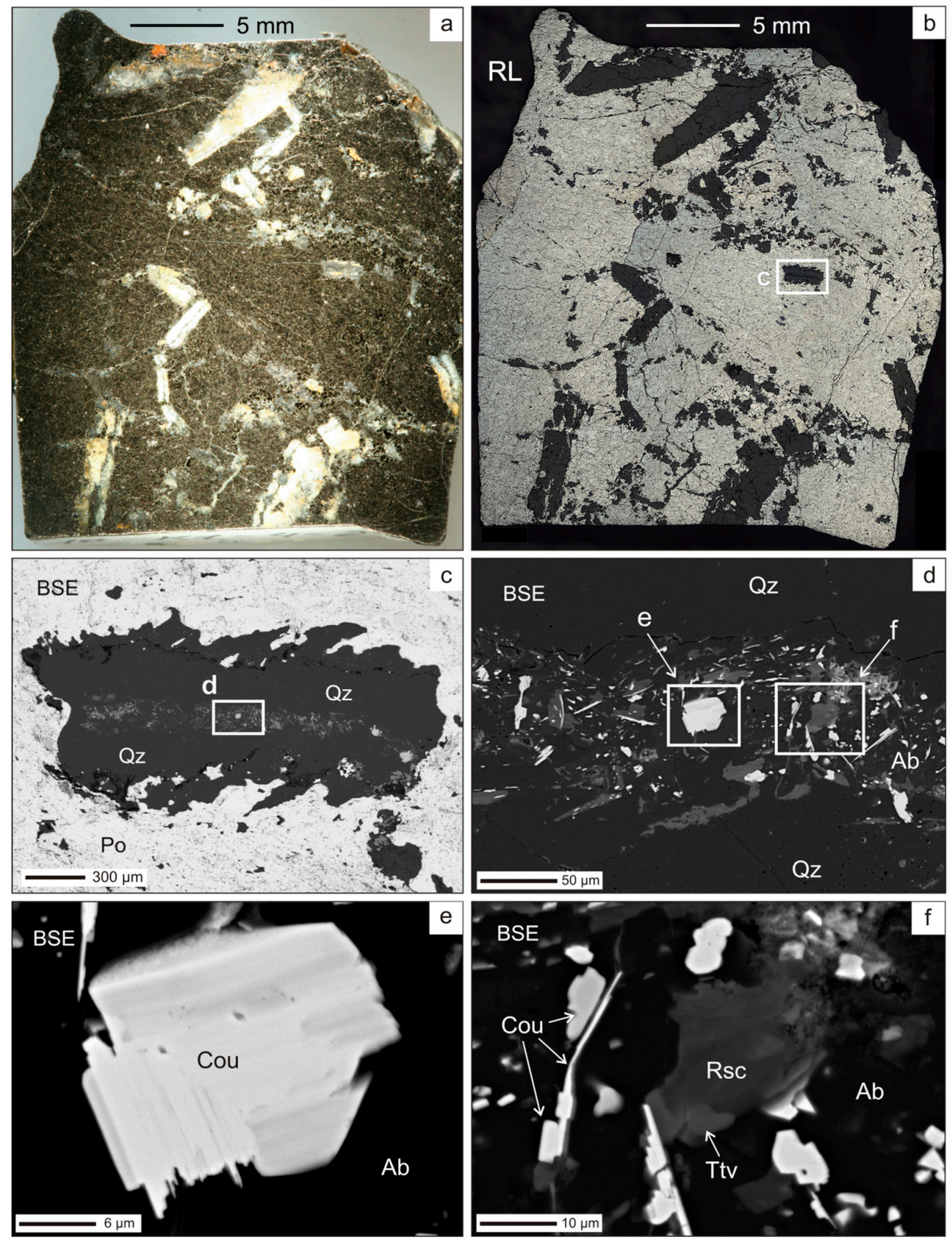

Figure 6. Appearance of a massive sulfide ore containing relics of quartz-albite veins in polished sample 16-K7-4-2 in ordinary (a) and reflected (b) light. (c) Zonal and banded structure of an elongated relic. (d-f) Internal structure (d) and mineralogy of the axial albite band (f). BSE and RL, back-scattered electron and reflected light images, respectively; $\mathrm{Ab}$, albite; Cou, coulsonite; $\mathrm{Qz}$, quartz; Rsc, roscoelite; $\mathrm{Ttv}$, thortveitite. 
The relics have a zonal and banded structure. Their axial band is composed of albite and two marginal bands are built up by quartz (Figure $6 \mathrm{~d}$ ). The albite axial band hosts a Cr-Sc-V-bearing mineralization (Figure 6e,f) which is represented by Fe-V oxides (coulsonite and its high-Ti variety, containing up to 18 mass $\%$ of $\mathrm{TiO}_{2}$, and nolanite), Ti- $\mathrm{V}$ oxides (tivanite, byrudite), as well roscoelite, V-bearing muscovite, V-bearing rutile and $\mathrm{Sc}-\mathrm{V}$-bearing crichtonite group minerals. It is notable that the scandium mineral thortveitite which contains up to 4 mass $\% \mathrm{~V}_{2} \mathrm{O}_{5}$ occurs in the albite axial bands (Figure $6 \mathrm{f}$ ). The $\mathrm{Cr}-\mathrm{Sc}-\mathrm{V}$-bearing mineralization suggests that scandium and vanadium were brought by hydrothermal fluids.

\subsection{Vanadium Mineralization not Related to Sulfide Ores}

In addition to massive sulfide ores, vanadium and vanadium-bearing minerals are also found in rocks not related to sulfide ores but somehow connected with supracrustal units of the western part of the Imandra-Varzuga structure. A large xenolith of volcanogenic rocks in the foyaites of the Devonian Khibiny alkaline massif exposed on the Mt. Kaskasnyunchorr contains vuorelainenite, a member of the spinel group, which is associated with a V-bearing crichtonite and karelianite and often forms thin rims around the inclusions of rutile in pyrrhotite [50,51]. Vuorelainenite and karelianite are characterized by the high $\mathrm{Cr}_{2} \mathrm{O}_{3}$ content (up to 29 and 12 mass \%, respectively). A small admixture of vanadium (less than 1 mass $\%$ of $\mathrm{V}_{2} \mathrm{O}_{3}$ ) is established in ilmenite and hematite. The $\mathrm{V}$ content in the crichtonite group minerals reaches 13.80 mass $\%$ of $\mathrm{V}_{2} \mathrm{O}_{3}$, but it usually is less than 1 mass $\%$. Scandium in the minerals of this group is not established [52].

Minerals of the natalyite-aegirine series and vanadates of rare-earth elements are found in alkaline metasomatites, similar in their mineral composition to fenites, on the contact of basic volcanics with dolomites in the Dolomite Quarry which is located in the south from the Pyrrhotite Ravine deposit [53] (Figure 2). As an admixture vanadium is also detected in magnesioriebeckite (up to 1.3 mass \% of $\mathrm{V}_{2} \mathrm{O}_{3}$ ). The $\mathrm{V}_{2} \mathrm{O}_{5}$ content in one analyzed sample of metasomatites is $0.41 \%$.

\section{Vanadium Mineralization Throughout the World}

\subsection{Vihanti, Finland}

The Lampinsaari ore complex is located in intensely metamorphosed Paleoproterozoic mica gneisses with amphibolite intercalations in the Vihanti-Pyhäsalmi Zn-ore belt in the Svecofennides which adjoin the Archean Karelian Province [54]. The complex consists predominantly of acid metavolcanics, dolomites, skarns, and cordierite gneisses which host ore bodies. The general structure of the Lampinsaari ore complex was formed by an overthrust. Phosphorite bands and a phosphatic metatuff contain uraninite and uranium-bearing apatite, respectively. A "lead model age" from galena is $1.94 \mathrm{Ga}$, a Pb-Pb isochron age for quartz porphyry is $1.92 \mathrm{Ga}$, syntectonic plutons is 1.90 and $1.89 \mathrm{Ga}$ (U-Pb, zircon) [54]. In supracrustal rocks of the Vihanti zinc ore deposit the $\mathrm{V}$ content usually does not exceed 0.03 mass $\%$ of $\mathrm{V}_{2} \mathrm{O}_{5}$. The highest amount of vanadium was determined in a graphite tuff (black schist) where the $\mathrm{V}_{2} \mathrm{O}_{5}$ concentration reaches 0.17 mass \% [55]. Ore minerals are sphalerite (zinc) and pyrite-pyrrhotite (massive sulfide) [54]. A vanadium mineralization is located in the massive sulfides and is represented by simple oxides (karelianite and shcherbinaite $\mathrm{V}_{2} \mathrm{O}_{5}$ ), $\mathrm{Fe}-\mathrm{V}$ oxides (coulsonite and nolanite), and Ti- $\mathrm{V}$ oxides (schreyerite $\mathrm{V}_{2} \mathrm{Ti}_{3} \mathrm{O}_{9}$, kyzylkumite, berdesinskiite $\mathrm{V}_{2} \mathrm{TiO}_{5}$, and tivanite) (Table 1) [16]. A chromium admixture is characteristic of these minerals. There is no data about vanadium or vanadium-bearing silicates in Vihanti.

\subsection{Outokumpu, Finland}

Ore bodies of the Outokumpu deposit are located in Paleoproterozoic supracrustal rocks which include black schists, quartzites, dolomites, and chrome-bearing skarns, as well as in serpentinites that are connected with the c. $1.95 \mathrm{Ga}$ Outokumpu ophiolite complex [56,57]. The $\mathrm{V}_{2} \mathrm{O}_{5}$ content in micaceous schists is 0.03 mass \%, in argillaceous black schists 0.11 mass \%, in siliceous schists 
0.02 mass \% and in serpentinites 0.01 mass \% [56]. The Outokumpu ore bodies occur in sheared quartzites near their contacts with serpentinites and are broken down by faults into several blocks. The main ore minerals are pyrrhotite $(23.2 \%)$, pyrite $(21 \%)$, chalcopyrite $(11 \%)$, and sphalerite $(1.7 \%)$ [56]. Cobaltpentlandite, cubanite, mackinawite, magnetite, and stannite are also established [56]. Vanadium minerals are represented by karelianite which was described here in the first time in the world, vourelainenite, and nolanite [15]. The skarns are usually chromium-bearing and contain rare chromium minerals such as eskolaite $\mathrm{Cr}_{2} \mathrm{O}_{3}$, uvarovite, chrome diopside, chrome tremolite, and some others [56,58].

\subsection{Sütra, Sweden}

Pyrite-pyrrhotite ores of the Sätra deposit are located in the Doverstorp ore field which is typical of the Ammeberg-Tunaberg metallogenic belt in the southern Paleoproterozoic Bergslagen Province [17,59]. The supracrustal section in the Bergslagen Province consists of mainly 1.90-1.89 Ga felsic volcanics with subordinate sediments, including marble and basic volcanics that were accumulated in an island-arc environment and then were deformed and metamorphosed under conditions of predominantly upper greenschist to upper amphibolite facies [60]. The main mineral is pyrrhotite, in a smaller amount pyrite, chalcopyrite, and sphalerite are present. Accessory minerals are represented by galena, alabandite, gudmundite, freibergite, pyrophanite, rutile, spessartite, and some others. In the Sätra pyrite-pyrrhotite ores, vourelainenite (up to 31 mass $\%$ of $\mathrm{Cr}_{2} \mathrm{O}_{3}$ ) and schreyerite also were described, with the former having been discovered for the first time in the world [17]. Vanadium as an isomorphic admixture was found in rutile (up to 1.7 mass $\%$ of $\mathrm{V}_{2} \mathrm{O}_{3}$ ) and manganochromite (up to 33 mass $\%$ of $\mathrm{V}_{2} \mathrm{O}_{3}$ ) [17].

\subsection{Rampura Agucha, India}

The Rampura Agucha $\mathrm{Zn}-\mathrm{Pb}-(\mathrm{Ag})$ stratiform deposit is located in supracrustal rocks of the Bhilwara belt at a contact with an Archean gneiss complex [18,61]. The Bhilwara belt is a thick pile of mainly metasedimentary rocks deposited during an intracratonic rifting of an Archean basement c. $2.0 \mathrm{Ga}$ ago. A Pb model age of the Rampura Agucha deposit is $1.8 \pm 0.04 \mathrm{Ga}$ [62]. The deposit is located in sillimanite- and graphite-bearing mica schists, garnet-biotite-sillimanite gneisses, and amphibolites. A V mineralization predominantly occurs in graphite-sillimanite-mica schists which are enriched by vanadium and nickel [63]. The main vanadium minerals are karelianite, coulsonite, and schreyerite. Vanadium-bearing minerals are represented by eskolaite, chromite, and rutile. Like their host rocks, the Rampura Agucha ores were metamorphosed under upper amphibolite-facies conditions $[63,64]$. The source of vanadium and chromium may be an organic matter in black shales. Vanadium and chromium were released due to metamorphism and formed their oxides [18].

\subsection{Biggejavri, Norway}

The Biggejavri U-Sc-REE occurrence is located in the Paleoproterozoic Kautokeino volcano-sedimentary belt in Finnmark [45]. The supracrustal succession of this belt is dominated by basic volcanics and includes sandstones, and quartzites deposited in a rift basin. Supracrustals were highly deformed under upper greenschist/amphibolites-facies conditions during the Svecofennian orogeny 1.9-1.7 Ga ago. Specific features of deformation are numerous shear zones, including thrust-related, with the Bidjovagge gold mineralization being controlled by a shear zone [65]. Uranium, scandium and rare-earth-bearing mineralization is situated in albite felsites in the lower units of the belt. The origin of the albite felsites is currently under study. The albite felsites are slightly radioactive, medium- to fine-grained, and consist of more than $90 \%$ albite. These rocks also contain calcite, quartz, muscovite, chromite, rutile and $\mathrm{Cr}-\mathrm{Sc}-\mathrm{V}-$ bearing crichtonite group minerals (1-8 mass \% of $\mathrm{V}_{2} \mathrm{O}_{3}$, 7-12 mass \% of $\mathrm{Cr}_{2} \mathrm{O}_{3}, 0.2-0.6$ mass \% of $\mathrm{Sc}_{2} \mathrm{O}_{3}$ ). Accessories are represented by monazite, thortveitite, brannerite, $\mathrm{Cr}$-rich chlorite and others. The maximum $\mathrm{V}$ content in the albite felsites is $1100 \mathrm{ppm}$ (the average 909 ppm) whereas the maximum Sc content is 136 ppm [45]. 


\subsection{Deadhorse Creek, Canada}

The Proterozoic Deadhorse Creek volcanoclastic breccia complex is located in Archean metasedimentary and metavolcanic rocks of the Schreiber-White River greenstone belt adjacent to the $1.11 \mathrm{Ga}$ Coldwell alkaline complex [47]. This complex contains a metasomatically-altered breccia, a U-Be-Zr-rich mineralized zone, and a Zr-Y-Th-rich carbonate vein. A U-Pb zircon age of the U-Be mineralization is $1129 \pm 6 \mathrm{Ma}$. The main minerals of the mineralized zone are represented by albite, potassium feldspar, quartz, calcite, and phenakite. Accessories include minerals of the aegirine-jervisite and aegirine-natalyite series, allanite, Ca-Mn silicates, $\mathrm{Nb}-\mathrm{V}$-bearing rutile [66], pyrite, thorite, thortveitite, xenotime, $\mathrm{Sc}-\mathrm{Nb}-\mathrm{V}$-bearing crichtonite group minerals, and others [47]. The formation of this unusual mineralization occurred under the influence of $\mathrm{CO}_{2}$-bearing and $\mathrm{Cr}-\mathrm{Nb}$-V-Ti-enriched alkaline fluids whose source remains enigmatic [47].

\section{Discussion}

\subsection{Structural Position and Age of the Sulfide Ores in Pechenga-Varzuga}

Based on a plate-tectonic model suggested in [25], the structural position of the studied sulfide ores has been determined. The model consists of Paleoproterozoic rifting that resulted from lithospheric thinning above a mantle plume head, oceanic separation, subduction, collision and post-orogenic relaxation. All these processes led to the development of the Paleoproterozoic Lapland-Kola orogen, a Himalayan-scale, high-pressure, collisional belt traceable across the Atlantic $[67,68]$. Rifting was occurring approximately from $2.53 \mathrm{Ga}$ to $2.0 \mathrm{Ga}$ (see reviews in $[23,24])$. The continental break-up and opening of the Lapland-Kola Red Sea type ocean happened south-west of the Pechenga-Imandra-Varzuga suture (PIV in Figure 1) c. 2.05 Ga [20] or c. 1.99 Ga ago [22]. These dates constrain a change of tectonic setting from a continental rifting to a passive continental margin [33]. The formation of subduction-related supracrustals (the Tominga and South Pechenga groups) and plutonic rocks was occurring from $1.97 \mathrm{Ga}$ to $1.91 \mathrm{Ga}[20,28,39,40,68]$. The oceanic crust was completely subducted, which explains why basalts that are free of continental admixture are lacking in the upper part of the North Pechenga Group [33]. In the Kola region the subduction occurred 1.93-1.91 Ga ago [20] and in Finnish lapland 1.90-1.88 Ga ago [68]. Within the orogenic core and the footwall of the Lapland-Kola orogen (Belomorian Province), the collision resulted in a regional set of shear zones which strongly affected margins of all tectonic units $[19,20]$. It is this shearing that resulted in a strong tectonic, metamorphic and metasomatic reworking of the Tominga and South Pechenga groups.

Sulfide ores of the Pyrrhotite Ravine deposit and the Bragino occurrence are situated at a distance of $200 \mathrm{~km}$ from each other in the Pechenga and Imandra-Varzuga structures, parts of the Paleoproterozoic Pechenga-Imandra-Varzuga riftogenic belt (Figures 1-3). Both the study areas are located in basalts that were sheared and metasomatically changed under conditions of low-grade metamorphism. The basalts belong to the uppermost parts of the stratigraphical section of these two structures deposited in an island-arc environment 1.90-1.96 Ga ago. The basalts were deformed in shear zones that belong to the aforementioned regional set of collisional shear zones. Shear zones are good conduits for metasomatizing fluids and can control the localization of ore mineralization $[69,70]$. Two stages of collision were distinguished: frontal and transpressional collisions occurred at the first and second stages, respectively [25]. These stages are separated by the intrusion of a $1916 \pm 10 \mathrm{Ma}$ quartz diorite in island-arc-related supracrustal rocks [71] occurring in the Tersk Terrane south of the Imandra-Varzuga structure (Figure 1).

Vanadium and vanadium-bearing minerals are characteristic of gold deposits located in Archean greenstone throughout the world and these deposits are often related to late collisional shear zones, the so-called orogenic gold [69,72-75]. In the Tersk Terrane transpressional shear zones contain sulfide ore occurrences some of which are gold-bearing and were formed during the latest events of the transpressional stage [71,76]. The massive appearance of the sulfide ores suggests that their recrystallization took place during terminational events of the transpressional stage. The formation of 
the sulfide ores seems to have been ended by 1.86-1.87 Ga when $\mathrm{Rb}$-Sr isotope systems were closed in rocks of the Bragino and Kaplya formations in the South Pechenga structural zone [36] and by 1.88-1.90 Ga, the time of closure of the Ar-Ar isotope system in hornblende in the Tersk terrane [77]. Therefore, the metamorphic recrystallization of the sulfide ores occurred in the Pyrrhotite Ravine and Bragino areas 1.86-1.90 Ga ago. This time interval is consistent with the main period (1.92-1.87 Ga) of formation of a syn- and post-orogenic gold and sulfide (mainly pyrrhotite) mineralization related to shear zones in the Central Lapland Greenstone Belt in northern Finland [78].

\subsection{Comparative Analysis of Vanadium Mineralization in Kola and Other Regions}

Comparison of the mineral compositions of the Pyrrhotite Ravine and Bragino sulfide ores demonstrates that these are principally similar. The only difference is that the Pyrrhotite Ravine deposit contains calcium silicates (goldmanite, mukhinite, and others, Table 1) which are spatially and genetically related to oxides and are lacking in the Bragino sulfide ores. This difference reflects, however, a contact metamorphism and metasomatism (a calcium input) that were produced by the giant Devonian Khibiny alkaline intrusion (Figure 2) and resulted in the formation of skarns. A similar in some extent example is reported from Silurian Sedex deposits in Spain [46]. In these deposits Vand $\mathrm{Cr}$-rich mineral associations are the result of low-grade regional and subsequent medium- and high-grade contact metamorphism of pelitic rocks. Both of these metamorphic events were, however, isochemical. The protoliths contained abundant organic matter and were originally enriched in $\mathrm{V}$ and $\mathrm{Cr}$.

Another principal similarity of the Pyrrhotite Ravine and Bragino sulfide ores is the scandium mineralization which associates with the vanadium minerals and is lacking in sulfide ores in other regions of the world (Table 1). It suggests that the metamorphic recrystallization of the Pyrrhotite Ravine and Bragino sulfide ores and the simultaneous development of the vanadium and scandium mineralization were produced from a mineral-forming process in the same environment. The identity of structural and tectonic positions of the Pyrrhotite Ravine and Bragino sulfide ores favors this suggestion.

A vanadium mineralization similar to that in the Pyrrhotite Ravine and Bragino sulfide ores is described in the Vihanti and Outokumpu deposits in Finland [15,16], the Sätra deposit in Sweden [17] and the Rampura Agucha deposit in India [18]. These deposits are also located in Paleoproterozoic sequences and were metamorphosed at low-grade and medium-grade conditions during Paleoproterozoic orogenies. Sulfide ores of the Lemarchant deposit in Canada [79] and the Waterloo deposit in Australia [80] bear vanadium sulfides sulvanite $\mathrm{Cu}_{3} \mathrm{VS}_{4}$ and colusite $\mathrm{Cu}_{12} \mathrm{VAs}_{3} \mathrm{~S}_{16}$ which have not been found in the Pyrrhotite Ravine and Bragino sulfide ores. In contrast to the Kola sulfide ores, the Lemarchant sulfide ores preserved an early exhalative/epithermal-type mineralization formed at temperature of $150-250{ }^{\circ} \mathrm{C}$, whereas the Waterloo sulfide ores are located in rocks metamorphosed predominantly under lower greenschist-facies conditions.

A vanadium mineralization that is not linked with the formation of sulfide ores is reported from the Biggejavri deposit in Norway [45] and the Deadhorse Creek deposit in Canada [47]. The former is located in a Paleoproterozoic rift-related supracrustal succession and was metamorphosed at medium-grade metamorphic conditions during the Svecofennian orogeny. The V mineralization in the Deadhorse Creek deposit, however, is situated in an Archean greenstone belt and has a Mesoproterozoic age. This is thought to have resulted from an interaction between earlier mineral assemblage that was developed at the invasion of "granitic" magmatic melts / fluids in a fault and later Nb-Ti-V-Cr-bearing alkaline fluids introduced into the same fault.

So, the vanadium mineralization in sulfide ores in which major minerals are vanadium oxides is linked with metamorphic recrystallization of primary sulfide ores at upper greenschist-facies/upper amphibolite-facies conditions. The vanadium mineralization was accompanied by chromium and scandium mineralizations. The simultaneous development of these three mineralizations is a unique feature of sulfide ores only in the Kola region. Scandium is thought to have been brought by 
metasomatizing fluids which introduced vanadium into shear zones. The scandium mineralization that is not related to sulfide ores is reported from the Biggejavri deposit in Norway [45] and the Deadhorse Creek deposit in Canada [47].

\subsection{Source of Vanadium}

Supracrustal rocks which host almost all the listed sulfide ore deposits and occurrences contain carbon-bearing black schists. Sedimentary protoliths of these rocks are accumulated in marine basins, and their formation is associated with underwater volcanic eruptions and biological activity during the Earth's evolution since the Archean [81,82]. Seawater extracts vanadium from basalt and then organic matter absorbs vanadium $[83,84]$. Thus, the source of vanadium and some other elements in the sediments can be sea water and an organic suspension in it, which precipitates together with sulfides and is captured by them [85]. A source of vanadium in sea water also is detritus of weathered continental rocks. Diagenesis, catagenesis and metamorphism result in the change of the organic form of vanadium into the mineral form, as well as in the removal of water from sediments and possible vanadium transportation by these fluids. Organic matter in schists is considered as a source of vanadium in the Rampura Agucha deposit [18] and the Sedex deposits [46].

A source of chromium which accompanies vanadium in all the listed deposits could be chromite often found in massive sulfide ores which are connected with mafic-ultramafic complexes similar to, for example, complexes in the Urals in Russia [86]. A primary enrichment of sediments in chromium associated with vanadium is described in [18,46]. As to scandium, the $\mathrm{Sc}_{2} \mathrm{O}_{3}$ concentration is $0.00004 \mathrm{ppm}$ in seawater, whereas the concentration of scandium originated from weathered igneous rocks should have been much higher, c. 3 ppm [87]. This suggests that scandium seems to be almost completely extracted by sediments from sea water.

Metamorphism of primary pyrite ores formed in oceanic basalts led to the mobilization of ore elements located in sulfides in the dispersed state and to their concentration in ore minerals up to the formation of their own mineral phases $[86,88,89]$. Secondary hydrothermal stages and local metamorphism of sulfide ores resulted in redistribution of base and precious metals, refining of common sulfides, the appearance of submicroscopic and microscopic inclusions of Au-Ag alloys, and segregation of trace elements into new, discrete minerals [88]. It is quite possible that metamorphic recrystallization of sulfides can form vanadium oxides.

The findings of V-Sc-bearing minerals in relics of primary hydrothermal veins in the Bragino sulfide ores suggest that these veins were formed at a hydrothermal event that preceded the metamorphic recrystallization of the sulfide ores. A similar genesis of vanadium minerals is attributed to a metamorphic recrystallization of the Vihanti sulfide ores originally enriched in vanadium [16,46]. We think that the hydrothermal event in Bragino was more likely related to a hydrothermal alteration of basalts that occurred immediately after their eruption and resulted in extraction from them of vanadium and scandium. In basalts of the Mennel Formation, however, the contents of vanadium, scandium and chromium are 160-450 ppm, 19-36 ppm and 180-2300 ppm, respectively [48]. So, this vanadium abundance is just slightly higher than that in the Earth's crust, 138 ppm [90], whereas this scandium concentration practically coincides with its average content in the Earth's crust varying from 14 to 31 ppm [91]. These data suggest that the rocks hosting the Pyrrhotite Ravine and Bragino sulfide ores can hardly have been the only source of vanadium and scandium.

The Pyrrhotite Ravine and Bragino vanadium-bearing sulfide ores host a scandium mineralization which is not mentioned in other vanadium-bearing sulfide ore deposits described above (Table 1 ). The Pyrrhotite Ravine sulfide ores contain $\mathrm{Nb}$-V-W-bearing rutile (up to 12,13 and 4 mass percent of $\mathrm{V}_{2} \mathrm{O}_{3}, \mathrm{WO}_{3}$ and $\mathrm{Nb}_{2} \mathrm{O}_{5}$, respectively) and vanadium-bearing muscovite, and the Bragino sulfide ores bear roscoelite (Table 1). Taking into account the metamorphic recrystallization of the sulfide ores during terminational events of the Lapland-Kola orogeny 1.86-1.90 Ga ago and a simultaneous metasomatic reworking of their host, we believe that hydrothermal metasomatizing fluids that circulated in shear zones could have been an additional source of vanadium and scandium. 


\section{Conclusions}

1. Two types of vanadium mineralization which is rare in nature have been discovered in the Kola region. The mineralization includes both vanadium and vanadium-bearing minerals. Both mineralization types are located in supracrustal rocks of the Paleoproterozoic Pechenga-Varzuga riftogenic belt.

2. The first vanadium mineralization type is characteristic of sulfide ores and was studied in the Pyrrhotite Ravine deposit and the Bragino occurrence in the Imandra-Varzuga and Pechenga structures, respectively. These sulfide ores are hosted by island-arc-related basic metavolcanics of the Tominga Group (Imandra-Varzuga) and the South Pechenga Group (Pechenga). The rocks were metamorphosed under upper greenschist/lower amphibolite-facies conditions.

3. The first type of vanadium mineralization is localized in shear zones of the transpressional (late collisional) stage of the Paleoproterozoic Lapland-Kola collisional orogeny and was developed 1.90-1.86 Ga ago. This mineralization originated from a metamorphic recrystallization of sulfide ores that were originally enriched in vanadium and are thought to have formed during hydrothermal alteration of marine basalt. An additional input of vanadium is suggested to have been provided by metasomatizing fluids that circulated in the shear zones.

4. A unique feature of the first vanadium mineralization type is that it is accompanied by chromium and scandium mineralization. Scandium is believed to have been brought simultaneously with vanadium by metasomatizing fluids introduced in Paleoproterozoic shear zones. Scandium mineralization is not mentioned in sulfide ores that bear vanadium mineralization in other regions of the world.

5. The second type of vanadium mineralization is reported from the western part of the Imandra-Varzuga structure. It is localized in xenoliths of the Imandra-Varzuga basic metavolcanics in the 365 Ma Khibiny alkaline massif $[47,48]$ and mineralized rocks are similar to fenites alkaline metasomatic rocks at a contact between island-arc-related basic metavolcanics and dolomites of the Tominga Group [49]. The formation of this vanadium mineralization type is related to a contact metamorphism and alkaline metasomatism produced by the giant Khibiny alkaline intrusion.

Author Contributions: Mineralogical investigation of the Bragino occurrence, mineralogical literature review and illustration preparation, A.A.K.; mineralogical investigation of the Pyrrhotite Ravine deposit and other objects in the Imandra-Varzuga structure, A.V.V.; regional geology review, structural position and age of the studied sulfide ores, V.V.B.

Funding: This research was funded by the Geological Institute of the Kola Science Centre of the RAS in the context of scientific themes 0231-2015-0001 and 0231-2015-0004; a study of the Paleoproterozoic metamorphic and deformational history in the Kola region was partly funded by RFBR grant 16-05-01031A.

Acknowledgments: The authors thank A.V. Bazai, Ye.E. Savchenko, E.A. Selivanova, and M.Yu. Glazunova from the Geological Institute of the Federal Research Center Kola Science Center of the Russian Academy of Sciences, and N.S. Vlasenko, V.V. Shilovskikh, and V.N. Bocharov from the Resousce Center "Geomodel" of the Saint Petersburg State University for helping in mineralogical investigations. R.V. Kislitsyn from the Dalhousie University in Halifax is thanked for correcting the manuscript. We are grateful to two anonymous reviewers and the Academic Editor whose notes helped us to make the manuscript stricter and more understandable.

Conflicts of Interest: The authors declare no conflict of interest.

\section{References}

1. Emsley, J. The Elements, 2nd ed.; Clarendon Press: Wotton-under-Edge, UK, 1991; p. 260, ISBN 0198555687.

2. Voytekhovsky, Y.L.; Neradovsky, Y.N.; Grishin, N.N.; Rakitina, E.Y.; Kasikov, A.G. The Kolvitsa ore deposit (geology, chemical and mineral composition of ores). Proc. Murm. State Tech. Univ. 2014, 17, 271-278. (In Russian)

3. Cawthorn, R.G. The Bushveld Complex, South Africa. In Intrusions; Charlier, B., Namur, O., Latypov, R., Tegner, C., Eds.; Springer Science+Business Media: Dordrecht, The Netherlands, 2015; pp. 517-587. 
4. Fischer, L.A.; Yuan, Q. Fe-Ti-V-(P) resources in the upper zone of the Bushveld complex, South Africa. Pap. Proc. R. Soc. Tasman. 2016, 150, 15-22. [CrossRef]

5. Yao, Y.; Viljoen, M.J.; Viljoen, R.P.; Wilson, A.H.; Zhong, H.; Liu, B.G.; Ying, H.L.; Tu, G.Z.; Luo, N. Geological characteristics of PGE-bearing layered intrusions in Southwest Sichuan province, China. In Economic Geology Research Unit. Information Circular; University of the Witwatersrand: Johannesburg, South Africa, 2001; p. 17, ISBN 1-86838-302-4.

6. Zhou, M.F.; Wang, C.Y.; Pang, K.N.; Shellnutt, G.J.; Ma, Y. Origin of giant Fe-Ti-V oxide deposits in layered gabbroic intrusions, Pan-Xi district, Sichuan Province, SW China. In Mineral Deposit Research: Meeting the Global Challenge, Proceedings of the Eighth Biennial SGA Meeting, Beijing, China, 18-21 August 2005; Mao, J., Bierlein, F.P., Eds.; Springer: Berlin/Heidelberg, Germeny, 2005; pp. 511-513.

7. Radtke, A.S. Coulsonite, $\mathrm{FeV}_{2} \mathrm{O}_{4}$, a spinel-type mineral from Lovelock, Nevada. Am. Mineral. 1962, 47, 1284-1291.

8. Harris, C.; Hlongwane, W.; Gule, N.; Scheepers, R. Origin of tanzanite and associated gemstone mineralization at Merelani, Tanzania. S. Afr. J. Geol. 2014, 117, 15-30. [CrossRef]

9. Reznitsky, L.Z.; Skliarov, E.V.; Ushchapovskaia, Z.F. Natalyite $\mathrm{Na}(\mathrm{V}, \mathrm{Cr}) \mathrm{Si}_{2} \mathrm{O}_{6}-\mathrm{A}$ new chromium-vanadium pyroxene from Slyudianka. Proc. Russ. Mineral. Soc. 1985, 114, 630-635. (In Russian)

10. Reznitsky, L.Z.; Sklyarov, E.V.; Ushchapovskaya, Z.F. Magnesiocoulsonite $\mathrm{MgV}_{2} \mathrm{O}_{4}-\mathrm{A}$ new mineral species in the spinel group. Proc. Russ. Mineral. Soc. 1995, 124, 91-98. (In Russian)

11. Reznitsky, L.Z.; Sklyarov, E.V.; Armbruster, T.; Ushchapovskaya, Z.F.; Galuskin, E.V.; Polekhovsky, Y.S.; Barash, I.G. The new mineral oxyvanite $\mathrm{V}_{3} \mathrm{O}_{5}$ and the oxyvanite-berdesinskiite $\mathrm{V}_{2} \mathrm{TiO}_{5}$ isomorphic join in metamorphic rocks of Sludyanka complex (South Baikal region). Proc. Russ. Mineral. Soc. 2009, 138, 70-81. (In Russian)

12. Kompanchenko, A.A.; Voloshin, A.V.; Bazai, A.V.; Polekhovsky, Yu.S. Evolution of a chromium-vanadium mineralization in massive sulfide ores at the Bragino occurrence in the South Pechenga structural zone (Kola region): An example of the spinel group minerals. Proc. Russ. Mineral. Soc. 2017, 146, 44-59. (In Russian)

13. Karpov, S.M.; Voloshin, A.V.; Savchenko, Ye.E.; Selivanova, E.A. Vanadium-bearing minerals in ores of the Pyrrhotite Ravine massive sulfide deposit (Khibiny region, Kola peninsula). Proc. Russ. Mineral. Soc. 2013, 142, 83-99. (In Russian)

14. Karpov, S.M.; Voloshin, A.V.; Kompanchenko, A.A.; Savchenko, Y.E.; Bazai, A.V. Crichtonite group minerals in massive sulfide ores and ore metasomatites of the Proterozoic structures of the Kola region. Proc. Russ. Mineral. Soc. 2016, 145, 39-56. (In Russian)

15. Long, J.V.P.; Vourelainen, Y.; Kuovo, O. Karelianite, a new vanadium mineral. Am. Mineral. 1963, 48, $33-41$.

16. Sergeeva, N.E.; Eremin, N.I.; Dergachev, A.L. Vanadium mineralization in ore of the Vihanti massive sulfide base-metal deposit, Finland. Dokl. Earth Sci. 2011, 436, 210-212. [CrossRef]

17. Zakrzewski, M.A.; Burke, E.A.J.; Lustenhouwer, W.J. Vourelainenite, a new spinel, and associated minerals from the Sätra (Doverstorp) pyrite deposit, central Sweden. Can. Mineral. 1982, 20, 281-290.

18. Höller, W.; Stumpfl, E.F. Cr-V oxides from the Rampura Agucha Pb-Zn-(Ag) deposit, Rajasthan, India. Can. Mineral. 1995, 33, 745-752.

19. Balagansky, V.V.; Glaznev, V.N.; Osipenko, L.G. Early Proterozoic evolution of the northeastern Baltic Shield: Terrane analysis. Geotectonics 1998, 32, 81-93.

20. Daly, J.S.; Balagansky, V.V.; Timmerman, M.J.; Whitehouse, M.J. The Lapland-Kola Orogen: Palaeoproterozoic collision and accretion of the northern Fennoscandian lithosphere. In European Lithosphere Dynamics; Gee, D.G., Stephenson, R.A., Eds.; Memoir 32; Geological Society: London, UK, 2006; pp. 579-598.

21. Glebovitsky, V.A. (Ed.) Early Precambrian of the Baltic Shield; Nauka: Saint-Petersburg, Russia, 2005; p. 711, ISBN 5-02-024950-5. (In Russian)

22. Melezhik, V.A.; Sturt, B.A. General geology and evolutionary history of the early Proterozoic Polmak-Pasvik-Pechenga-Imandra/Varzuga-Ust'Ponoy Greenstone Belt in the north-eastern Baltic Shield. Earth Sci. Rev. 1994, 36, 205-241. [CrossRef]

23. Melezhik, V.A.; Prave, A.R.; Hanski, E.J.; Fallick, A.E.; Lepland, A.; Kump, L.R.; Srauss, H. (Eds.) The Palaeoproterozoic of Fennoscandia as Context for the Fennoscandian Arctic Russia-Drilling Early Earth Project. In Reading the Archive of Earth's Oxygenation; Springer: Heidelberg, Germany, 2013; p. 490. 
24. Mints, M.V.; Dokukina, K.A.; Konilov, A.N.; Philippova, I.B.; Zlobin, V.L.; Babayants, P.S.; Belousova, E.A.; Blokh, V.I.; Bogina, M.M.; Bush, D.A.; et al. East European Craton: Early Precambrian History and 3D Models of Deep Crustal Structure; Geological Society of America Special Paper 510; Geological Society of America: Boulder, CO, USA, 2015; p. 433.

25. Rundqvist, D.V.; Mitrofanov, F.P. (Eds.) Precambrian Geology of the USSR. In Developments in Precambrian Geology 9; Elsevier: Amsterdam, The Netherlands, 1993; p. 528, ISBN 978-0-444-89380-2.

26. Zagorodny, V.G.; Predovsky, A.A.; Basalaev, A.A.; Batieva, I.D.; Borisov, A.E.; Vetrin, V.R.; Voloshina, Z.M.; Dokuchaeva, V.S.; Zhangurov, A.A.; Kozlova, N.E.; et al. Imandra-Varzuga Zone of the Karelides (Geology, Geochemistry, History of Development); Nauka: Leningrad, Russia, 1982; p. 280. (In Russian)

27. Petrov, V.P.; Belyaev, O.A.; Voloshina, Z.M.; Balagansky, V.V.; Glazunkov, A.N.; Pozhilenko, V.I. Endogenic Regimes of Early Precambrian Metamorphism; Nauka: Leningrad, Russia, 1990; p. 184, ISBN 5-02-024410-4. (In Russian)

28. Skuf'in, P.K.; Bayanova, T.B.; Mitrofanov, F.P. Isotope age of subvolcanic graditoid rocks of the early Proterozoic Panarechka volcanotectonic structure, Kola Peninsula. Dokl. Earth Sci. 2006, 409, 774-778. [CrossRef]

29. Mitrofanov, F.P.; Balashov, Y.A.; Balagansky, V.V. New geochronological data on lower Precambrian complexes of the Kola Peninsula. In Correlation of Lower Precambrian Formations of the Karelia-Kola Region, USSR, and Finland; Mitrofanov, F.P., Balagansky, V.V., Eds.; Kola Science Centre of the RAS: Apatity, Russia, 1991; pp. 12-16.

30. Smol'kin, V.F.; Mitrofanov, F.P.; Avedisyan, A.A.; Balashov, Y.A.; Balagansky, V.V.; Borisov, A.E.; Borisova, V.V.; Voloshina, Z.M.; Kozlova, N.E.; Kravtsov, N.A.; et al. Magmatism, Sedimentogenesis and Geodynamics of the Pechenga Paleorift; Kola Science Centre of the Russian Academy of Sciences: Apatity, Russia, 1995; p. 256. (In Russian)

31. Kozlovsky, E.A. (Ed.) The Superdeep Well in the Kola Peninsula; Springer: Berlin, Germany, 1987; p. 490.

32. Zagorodny, V.G.; Radchenko, A.T. Tectonics of the Karelides of the Northeastern Baltic Shield; Nauka: Leningrad, Russia, 1988; p. 110, ISBN 5-02-024361-2. (In Russian)

33. Hanski, E.J.; Huhma, H.; Melezhik, V.A. New isotopic and geochemical data from the Palaeoproterozoic Pechenga Greenstone Belt, NW Russia: Implication for basin development and duration of the volcanism. Precambrian Res. 2014, 245, 51-65. [CrossRef]

34. Martin, A.P.; Condon, D.J.; Prave, A.R.; Melezhik, V.A.; Lepland, A.; Fallick, A.E. Dating the termination of the Palaeoproterozoic Lomagundi-Jatuli carbon isotopic event in the North Transfennoscandian Greenstone Belt. Precambrian Res. 2013, 224, 160-168. [CrossRef]

35. Melezhik, V.A.; Huhma, H.; Condon, D.J.; Fallick, A.E.; Whitehouse, M.J. Temporal constraints on the Paleoproterozoic Lomagundi-Jatuli carbon isotopic event. Geology 2007, 35, 655-658. [CrossRef]

36. Balashov, Y.A. Paleoproterozoic geochronology of the Pechenga-Varzuga structure, Kola Peninsula. Petrology 1996, 4, 3-25.

37. Akhmedov, A.V.; Voronyaeva, L.V.; Pavlov, V.A.; Krupenik, V.A.; Kuznezov, V.A.; Sveshnikova, K.Yu. Gold potential of the South-Pechenga structural zone (Kola Peninsula): Occurrence types and prospects of discovery of economic gold content. Reg. Geol. Metallog. 2004, 20, 139-151. (In Russian)

38. Skuf'in, P.K.; Elizarov, D.V.; Zhavkov, V.A. Geological and geochemical pecularities of volcanics of the the South Pechenga structural zone. Proc. Murm. State Tech. Univ. 2009, 12, 416-435. (In Russian)

39. Skuf'in, P.K.; Bayanova, T.B.; Mitrofanov, F.P.; Apanasevich, E.A.; Levkovich, N.V. The absolute age of granitoids from the Shuoniyarvi pluton in the southern framework of the Pechenga structure, the Kola Peninsula. Dokl. Earth Sci. 2000, 370, 114-117.

40. Vetrin, V.R.; Turkina, O.M.; Rodionov, N.V. U-Pb age and genesis of granitoids in the southern framing of the Pechenga structure, Baltic Shield. Dokl. Earth Sci. 2008, 219, 806-810. [CrossRef]

41. Gorstka, V.N. The Contact Zone of the Khibiny Alkaline Massif (Geological and Petrographical Peculiarities, Chemistry and Petrology); Nauka: Leningrad, Russia, 1971; p. 99. (In Russian)

42. Fedotov, Z.A. The Evolution of Proterozoic Volcanism of the Eastern Pechenga-Varzuga Belt (Petrogeochemical Aspects); Kola Science Centre of the RAS: Apatity, Russia, 1985; p. 120. (In Russian) 
43. Konstantov, S.V.; Sobolev, I.I.; Surovtseva, O.E. The South Contact of the Khibiny Massif. Aykuayvenchorr-Vudyavrchorr-Takhtarvumchorr Areas. Report on Geological Exploration of Iron Sulphides in 1931-1935; Scientific Archive of Geological Institute of the Kola Science Centre of the RAS: Apatity, Russia, 1935; p. 408. (In Russian)

44. Whitney, D.L.; Evans, B.W. Abbreviations for names of rock-forming minerals. Am. Mineral. 2010, 95, 185-187. [CrossRef]

45. Olerud, S. Davidite-loveringite in early Proterozoic albite felsites in Finnmark, north Norway. Mineral. Mag. 1988, 52, 400-402.

46. Canet, C.; Alfonso, P.; Melgarejo, J.-C. V-rich minerals in contact-metamorphosed Silurian sedex deposit in the Poblet area, Southwestern Catalonia, Spain. Can. Mineral. 2003, 41, 561-579. [CrossRef]

47. Potter, E.G.; Mitchell, R.H. Mineralogy of the Deadhorse Creek volcaniclastic breccia complex, northwestern Ontario, Canada. Contrib. Mineral. Petrol. 2005, 150, 212-229. [CrossRef]

48. Skuf'in, P.K.; Theart, H.F.J. Geochemical and tectono-magmatic evolution of the volcano-sedimentary rocks of Pechenga and other greenstone fragments within the Kola Greenstone Belt, Russia. Precambrian Res. 2005, 141, 1-48. [CrossRef]

49. Raade, G.; Balić-Žunić, T.; Stanley, C.J. Byrudite, $(\mathrm{Be}, \square)\left(\mathrm{V}^{3+}, \mathrm{Ti}\right)_{3} \mathrm{O}_{6}$, a new mineral from the Byrud emerald mine, South Norway. Mineral. Mag. 2015, 79, 261-268. [CrossRef]

50. Mikhailova, Y.A.; Pakhomovsky, Y.A.; Menshikov, Y.P. Tausonite, baddeleyite and vuorelainenite from hornfels of mt. Kaskasnyunchorr (Khibiny massif). In Proceedings of the 1st Fersman Scientific Session; Geological Institute of the Kola Science Center: Apatity, Russia, 2004; pp. 28-29. (In Russian)

51. Mikhailova, Y.A.; Konopleva, N.G.; Yakovenchuk, V.N.; Ivanyuk, G.Y.; Men'shikov, Y.P.; Pakhomovsky, Y.A. Corundum-group minerals in rocks of the Khibiny alkaline pluton, Kola Peninsula. Geol. Ore Depos. 2007, 49, 590-598. [CrossRef]

52. Korchak, Y.A.; Pakhomovsky, Y.A.; Men'shikov, Y.P.; Ivanyuk, G.Y.; Yakovenchuk, V.N. Minerals of crichtonite group in hornfels of Khibiny massif. In Proceedings of the 5th Fersman Scientific Session; Geological Institute of the Kola Science Center: Apatity, Russia, 2008; pp. 264-265. (In Russian)

53. Karpov, S.M.; Voloshin, A.V.; Telezhkin, A.A. The natalyite-aegirine series in alkaline metasomatites of the Imandra-Varzuga belt, Kola region. Proc. Russ. Mineral. Soc. 2018, 147. in press (In Russian)

54. Rauhamäki, E.; Mäkelä, T.; Isomäki, O.-P. Geology of the Vihanti mine. In Precambrian ores of Finland. Guide to Excursions $078 \mathrm{~A}+\mathrm{C}$, Part 2 (Finland), Proceedings of the 26th International Geological Congress, Paris, France 7 July 1980; Häkli, T.A., Ed.; Geological Survey of Finland: Espoo, Finland, 1980; pp. 14-24.

55. Rouhunkoski, P. On the geology and geochemistry of the Vihanti zinc ore deposit, Finland. Bull. Comm. Geol. Finl. 1968, 236, 121.

56. Peltola, E. Origin of Precambrian Copper Sulfides of the Outokumpu Disctrict, Finland. Econ. Geol. 1978, 73, 461-477. [CrossRef]

57. Peltonen, P. Ophiolites. In Precambrian Geology of Finland-Key to the Evolution of the Fennoscandian Shield; Lehtinen, M., Nurmi, P.A., Rämö, O.T., Eds.; Elsevier: Amsterdam, The Netherlands, 2005; pp. 237-278.

58. Peltola, E. Geology of the Vuonos ore deposit. In Precambrian ores of Finland. Guide to excursions 078 A $+C$, Part 2 (Finland), Proceedings of the 26th International Geological Congress, Paris, France, 7 July 1980; Häkli, T.A., Ed.; Geological Survey of Finland: Espoo, Finland, 1980; pp. 33-41.

59. Wikström, A. Beskrivning till berggrundskartan Katrineholm SV. Sver. Geol. Unders. Ser. Af. 1976, 116, 88.

60. Allen, R.L.; Lunström, I.; Ripa, M.; Simeonov, A.; Christofferson, H. Facies analysis of a 1.9 Ga, contintental margin, back-arc, felsic caldera province with diverse $\mathrm{Zn}-\mathrm{Pb}-\mathrm{Ag}-(\mathrm{Cu}-\mathrm{Au})$ sulfide and Feoxide deposits, Bergslagen region, Sweden. Econ. Geol. 1996, 91, 979-1008. [CrossRef]

61. Höller, W.; Gandhi, S.M. Origin of tourmaline and oxide minerals from the metamorphosed Rampura Agucha Zn-Pb-(Ag) deposit, Rajasthan, India. Mineral. Petrol. 1997, 60, 99-110. [CrossRef]

62. Deb, M.; Thorpe, R.L.; Cumming, G.L.; Wagner, P.A. Age, source and stratigraphic implications of Pb isotope data for conformable, sediment-hosted, base metal deposits in the Proterozoic Aravalli-Delhi orogenic belt, northwestern India. Precambrian Res. 1989, 43, 1-22. [CrossRef]

63. Deb, M. Lithogeochemistry of rocks around Rampura Agucha massive zinc sulfide ore-body, NW India - implications for the evolution of a Proterozoic "Aulakogen". In Metallogeny Related to Tectonics of the Proterozoic Mobile Belts; Sarkar, S.C., Ed.; Balkhema: Rotterdam, The Netherlands, 1992; pp. 1-35. 
64. Gandhi, S.M.; Paliwal, H.V.; Bhatnagar, S.N. Geology and ore reserve estimates of Rampura Agucha lead zinc deposit, Bhilwara District. J. Geol. Soc. India 1984, 25, 689-705.

65. Henderson, H.C.; Viola, G.; Nasuti, A. A new tectonic model for the Palaeoproterozoic Kautokeino Greenstone Belt, northern Norway, based on high-resolution airborne magnetic data and field structural analysis and implications for mineral potential. Nor. J. Geol. 2015, 95, 339-363. [CrossRef]

66. Platt, R.G.; Mitchell, R.H. Transition metal rutiles and titanates from the Deadhorse Creek diatreme complex, northwestern Ontario, Canada. Mineral. Mag. 1996, 60, 403-413. [CrossRef]

67. Bridgwater, D.; Marker, M.; Mengel, F. The eastern extension of the early Proterozoic Torngat Orogenic Zone across the Atlantic. In Lithoprobe, Eastern Canadian Shield Onshore-Offshore Transect (ECSOOT); Wardle, R.J., Hall, J., Eds.; Report 27; Memorial University of Newfoundland: St. John's, NL, Canada, 1992; pp. 76-91.

68. Tuisku, P.; Huhma, H.; Whitehouse, M. Geochronology and geochemistry of the enderbite series in the Lapland Granulite Belt: Generation, tectonic setting, and correlation of the belt. Can. J. Earth Sci. 2012, 49, 1297-1315. [CrossRef]

69. Cox, S.F. Deformational controls on the dynamic of fluid flow in mesothermal gold system. In Fractures, Fluid Flow and Mineralization; McCaffrey, K.J.W., Lonergan, L., Wilkinson, J.J., Eds.; Geological Society London Special Publication: London, UK, 1999; pp. 123-140.

70. Ashworth, J.R.; Brown, M. An overview of diverse responses to diverse processes at high crustal temperatures. In High-Temperatuire Metamorphism and Crustal Anatexis; Ashworth, J.R., Brown, M., Eds.; Kluwer Academic Publishers: Dordrecht, The Netherlands, 1990; pp. 1-18.

71. Balagansky, V.V.; Mudruk, S.V. On the age of a Paleoproterozoic collision in the southeastern Kola region, Baltic shield. In Geology and Geochronology of Rock-Forming and Ore-Forming Processes in Crystalline Shields; Mitrofanov, F.P., Bayanova, T.B., Eds.; Kola Science Centre of the RAS: Apatity, Russia, 2013; pp. 13-16. (In Russian)

72. Goldfarb, R.J.; Groves, D.I.; Gardoll, S. Orogenic gold and geological time: A global synthesis. Ore Geol. Rev. 2001, 18, 1-75. [CrossRef]

73. Scott, K.M.; Radford, N.W. Rutile compositions at the Big Bell Au deposit as a guide for exploration. Geochem. Explor. Environ. Anal. 2007, 7, 353-361. [CrossRef]

74. Scott, K.M.; Radford, N.W.; Hough, R.M.; Reddy, S.M. Rutile compositions in the Kalgoorlie Goldfields and their implications for exploration. Aust. J. Earth Sci. 2011, 58, 803-812. [CrossRef]

75. Urban, A.J.; Hoskins, B.F.; Grey, I.E. Characterization of V-Sb-W-bearing rutile from the Hemlo gold deposit, Ontario. Can. Mineral. 1992, 30, 319-326.

76. Balagansky, V.V.; Belyaev, O.A. Gold-bearing shear zones in the Early Precambrian of the Kola Peninsula: A prognosis and the first results. In Petrography of the XXI Century. Petrology and Ore-Potential of the CIS Regions and the Baltic Shield; Mitrofanov, F.P., Fedotov, Z.A., Eds.; Kola Science Centre of the Russian Academy of Sciences: Apatity, Russia, 2005; Volume 3, pp. 37-38. (In Russian)

77. Daly, J.S.; Balagansky, V.V.; Timmerman, M.J.; Whitehouse, M.J.; de Jong, K.; Guise, P.; Bogdanova, S.; Gorbatschev, R.; Bridgwater, D. Ion microprobe U-Pb zircon geochronology and isotopic evidence supporting a trans-crustal suture in the Lapland Kola Orogen, northern Fennoscandian Shield. Precambrian Res. 2001, 105, 289-314. [CrossRef]

78. Molnár, F.; Middleton, A.; Stein, H.; O’Brien, H.; Lahaye, Y.; Huhma, H.; Pakkanen, L.; Johanson, B. Repeated syn- and post-orogenic gold mineralization events between 1.92 and $1.76 \mathrm{Ga}$ along the Kiistala Shear Zone in the Central Lapland Greenstone Belt, northern Finland. Ore Geol. Rev. 2018, 101, 936-959. [CrossRef]

79. Gill, S.B.; Piercey, S.J.; Layton-Matthews, D. Mineralogy and metal zoning of the Cambrian $\mathrm{Zn}-\mathrm{Pb}-\mathrm{Cu}-\mathrm{Ag}-\mathrm{Au}$ Lemarchant volcanogenic massive sulfide (VMS) deposit, Newfoundland. Can. Mineral. 2016, 54, 1307-1344. [CrossRef]

80. Wagner, T.; Monecke, T. Germanium-bearing colusite from the Waterloo volcanic-rock-hosted massive sulfide deposit, Australia: Crystal chemistry and formation of colusite-group minerals. Can. Mineral. 2005, 43, 655-669. [CrossRef]

81. Altermann, W.; Kazmierczak, J. Archean microfossils: A reappraisal of early life on Earth. Res. Microbiol. 2003, 154, 611-617. [CrossRef] [PubMed]

82. Ohkouchi, N.; Kuroda, J.; Taira, A. The origin of the Cretaceous black shales in the surface ocean ecosystem and its triggers. Proc. Jpn. Acad. Ser. B 2015, 91, 273-291. [CrossRef] [PubMed]

83. Yudovich, Y.E.; Ketris, M.P. Trace Elements in Black Shales; Nauka: Ekaterinburg, Russia, 1994; p. 304. 
84. Vine, J.D.; Tourtelot, E.B. Geochemistry of black shale deposits-A summary report. Econ. Geol. 1970, 65, 253-272. [CrossRef]

85. Butler, I.B.; Nesbitt, R.W. Trace element distribution in the chalcopyrite wall of a black smoker chimney: Insights from laser ablation inductively coupled plasma mass spectrometry (LA-ICP-MS). Earth Planet. Sci. Lett. 1999, 167, 335-345. [CrossRef]

86. Zaykov, V.V.; Maslennikov, V.V.; Zaykova, E.V.; Herrington, R. Ore-Formation and Ore-Facies Analyses of Massive Sulphide Deposits of the Ural Paleoocean; Institute of Mineralogy, the Ural Branch of Russian Academy of Sciences: Miass, Russia, 2001; p. 315. (In Russian)

87. Borisenko, L.F. Scandium: Main Features of its Geochemistry, Mineralogy, and Genetic Types of Ore Deposits; Academy of Sciences of the USSR: Moscow, Russia, 1961; p. 132. (in Russian)

88. Vikentiev, I.V. Precious metal and telluride mineralogy of large volcanic-hosted massive sulfide deposits in the Ural. Mineral. Petrol. 2006, 87, 305-326. [CrossRef]

89. Vikent'ev, I.V.; Yudovskaya, M.A.; Moloshag, V.P. Speciation of noble metals and conditions of their concentration in massive sulfide ores of the Urals. Geol. Ore Depos. 2006, 48, 77-107. [CrossRef]

90. Pouret, O.; Dia, A. Vanadium. In Encyclopedia of Geochemistry; White, W.M., Ed.; Springer: Cham, Switzerland, 2016.

91. Rudnick, R.L.; Gao, S. Composition of the continental crust. In Treatise on Geochemistry; Turekian, K.K., Holland, H.D., Eds.; Elsevier: Amsterdam, The Netherlands, 2003; pp. 1-64.

(C) 2018 by the authors. Licensee MDPI, Basel, Switzerland. This article is an open access article distributed under the terms and conditions of the Creative Commons Attribution (CC BY) license (http://creativecommons.org/licenses/by/4.0/). 